\title{
Overyielding of temperate deciduous tree mixtures is maintained under throughfall reduction
}

\author{
Hans Göransson • Michael T. Bambrick • \\ Douglas L. Godbold
}

Received: 20 January 2016 / Accepted: 18 May 2016/Published online: 27 May 2016

(C) The Author(s) 2016. This article is published with open access at Springerlink.com

\begin{abstract}
Background and aims A changing climate in the future with more severe drought events will affect the conditions for forest growth and vitality. Most knowledge on tree species response to drought is based on monocultures, even though many of the forests in the world consist of mixed stands. We aimed to investigate how trees respond to summer drought when grown in a three species mixture. Methods For two subsequent summers canopy throughfall, and subsequently soil water potential, was reduced using sub-canopy roofs in monocultures and mixtures of Betula pendula, Alnus glutinosa and Fagus sylvatica,.

Results The overyielding of the mixed stand was not affected by the drought using either above or below ground production, standing fine root biomass or soil respiration as parameters. However, Alnus glutinosa was the most negatively affected when growing in monoculture, whereas this species was less affected when growing in mixture. In contrast, Betula pendula
\end{abstract}

Responsible Editor: Susan Schwinning.

Electronic supplementary material The online version of this article (doi:10.1007/s11104-016-2930-1) contains supplementary material, which is available to authorized users.

H. Göransson $(\bowtie) \cdot$ D. L. Godbold

Institute of Forest Ecology, Universität für Bodenkultur (BOKU), Peter-Jordan-Straße 82, A-1190 Vienna, Austria

e-mail: hans.goeransson@boku.ac.at

M. T. Bambrick

School of Environment, Natural Resources and Geography,

Bangor University, Bangor, UK was most negatively affected when growing in mixture. Fagus sylvatica was least affected by the drought and maintained growth over the two years.

Conclusions A water demanding species as Alnus glutinosa can perform well in a mixture during drought and not be outcompeted. This is opposite to what is assumed in most models of forest responses to climate change.

Keywords Drought - Tree diversity - Soil respiration . Roots

\section{Introduction}

Climate models suggest that extreme events of drought will increase in many parts of the world (IPCC 2014), which will affect production as well as health of terrestrial ecosystems. Commonly drought reduces tree productivity (Breda et al. 2006), or may result in tree death due to carbon starvation or hydraulic failure (Breda et al. 2006; McDowell 2011). The 2003 drought in Europe reduced gross primary production by $30 \%$ across the continent (Ciais et al. 2005), and strongly reduced $\mathrm{CO}_{2}$ sequestration in tree stands throughout Europe (Breda et al. 2006). In grasslands, higher species richness has been found to be correlated with high resistance to and resilience after disturbance, such as drought (Loreau et al. 2001; Tilman and Downing 1994). For trees, drought effects have been studied extensively on individual tree species, and has shown that drought decreases growth and increases the sensitivity to insect 
attacks and diseases, thus increasing the likelihood of tree death (Mattson and Haack 1987). How tree species grown in a mixture react to drought is less clear (DeClerck et al. 2006; del Rio et al. 2014; Pretzsch et al. 2014; Zapater et al. 2013).

Many studies have shown that mixtures have a higher productivity than single species stands, known as overyielding (Loreau et al. 2001; Tilman and Downing 1994; Forrester 2014; Forrester et al. 2006b; Kelty 2006; Zhang et al. 2012; Jacob et al. 2013). Overyielding is linked to two mechanisms. (i) Spatialtemporal differences in growth can increase the access to resources (competitive production principle (Vandermeer 1989)) and (ii) species may improve the environment experienced by another species (the facilitative production principle (Vandermeer 1989)). Both the spatial and temporal differences between species, as well as the facilitation of other species in a mixed stand, may be affected by a stress factor such as drought. In mixed stands there could be complementary effects due to different root depths leading to more efficient uptake of water or facilitation effects via hydraulic lift of water from deep layer (Lebourgeois et al. 2013; Neumann and Cardon 2012). However, drought can also lead to a decrease in overyeilding as a complementary effects driving the overyielding may decrease in importance when growth is water limited (Forrester 2014). If a mixed stand for example is over yielding due to complimentary effects in light absorption, this may disappear under competition for water. Under competition for water photosythesis will be limited by stomatal conductance to $\mathrm{CO}_{2}$ rather than light. Thus increased overyielding due to drought events is most likely to occur in stands which growth is normal limited by water (Lebourgeois et al. 2013). This might explain the large variation in response in overyielding due to drought events. In a two species mixture of Fagus sylvatica and Picea abies, (Pretzsch et al. 2012) and in mixtures of up to 4 conifer species (DeClerck et al. 2006), a decrease in overyielding during years with drought was shown, whereas in a mixture of Picea abies, Fagus sylvatica and Quercus petraea (del Rio et al. 2014) an increase in overyielding was shown. However, these studies have been restricted to determination of the effects of drought on the above ground biomass. Investigations of effects on belowground parameters are rare, even though the alteration of the root production, root biomass and root:shoot ratio are important means of adjustment to altered soil moisture levels (Osunubi and
Davies 1981). To increase the ratio between water absorbing and transpiring surfaces, tree species adapted to more xeric conditions tend to have higher root:shoot ratios (Joslin et al. 2000). However, results in monocultures for both seedlings and mature trees grown under experimentally altered moisture regimes, or studied along moisture gradients, are again contradictory (Meier and Leuschner 2008; Pronk et al. 2002; Thomas 2000). Two general trends were shown: (i) an increase of root biomass in response to drought has mostly been observed in conifer species (Gower et al. 1992; Parker and Van Lear 1996), which are known to differ in their root growth strategies from deciduous broad-leaved trees (Bauhus and Messier 1999), (ii) a decrease of root biomass occurs in European deciduous tree species in response to drought (Chiatante et al. 2006; Fort et al. 1998). Fagus sylvatica has, however, been found to sustain or even increase root growth in the upper soil layers during drought (Mainiero and Kazda 2006).

The growth of neighbouring species can affect species traits, which aid adaptation to drought. For example, Fagus sylvatica has a deeper root system with higher specific root length when growing in mixture with Picea abies, than when growing in monoculture (Bolte and Villanueva 2006). Bolte and Villanueva (2006) suggest that a deeper root system will affect the capacity of Fagus sylvatica to acquire water and maintain carbon assimilation during drought. Thus, the relative sensitivity of a species to drought can be different when growing in mixture as compared to growing in monocultures (Grossiord et al. 2014).

Understanding the strategies of individual species, in response to drought, and how they interact in mixed stands during drought, is essential when trying to model response to drought at an ecosystem level (van der Molen et al. 2011; Zapater et al. 2013).

In this study, we examined both the above and belowground responses of Silver birch (Betula pendula), European beech (Fagus sylvatica) and Common alder (Alnus glutinosa) to drought when grown as single species stands and as a mixture of the three species. Many studies of the effects of drought on temperate forest tree species have used Fagus sylvatica (Granier et al. 2007; Meier and Leuschner 2008; Peuke et al. 2002), however, studies on Betula pendula (Aspelmeier and Leuschner 2006; Ranney et al. 1991; Zapater et al. 2013) and Alnus glutinosa (Schrader et al. 2005) are rare. These species were chosen, as they represent different functional groups. Alnus glutinosa is an N-fixing, 
water-demanding pioneer species, with high juvenile growth rates (Braun 1974). Betula pendula is a lightdemanding, early successional species with fast juvenile growth (Fischer et al. 2002). Lastly, Fagus sylvatica is shade tolerant and slow growing when juvenile (Ellenberg 1996), can persist in the understory, and often dominates late successional forests.

We used a sub-canopy roof to reduce throughfall input for two summer seasons, and measured changes in above and below ground biomass as well as soil respiration. We hypothesise that: (i) As water is probably not normally limiting growth, the overyielding in the mixed stand should decrease during drought and (ii) that interspecific competition alters the relative resistance of species to drought as compared to when grown in monoculture. (iii) This leads to that in the mixed stands different species may contribute to overyielding under drought than in the control.

\section{Materials and methods}

Study site

The Bangor DIVERSE experimental site was established at Henfaes Research Centre, Bangor University, North Wales, UK $\left(53^{\circ} 14^{\prime} \mathrm{N}, 4^{\circ} 01^{\prime} \mathrm{W}\right)$ in March 2004 on two fields with a total area of 2.36 ha. Soils are fine loamy brown earth over gravel (Rheidol series) and classified as Fluventic Dystrochrept in the USDA system (Smith et al. 2013). Soil texture was $48.2 \pm 1.3 \%$ sand, $33.6 \pm 0.9 \%$ silt and $18.2 \pm 2.1 \%$ clay, determined by laser diffraction (Coulter LS particle size analyser). The soil pH is 5.4 in the $0-10 \mathrm{~cm}$ layer increases to 6.3 at $100 \mathrm{~cm}$ soil depth. Climate at the site is classified as hyperoceanic. Estimates of annual precipitation at the site were obtained from a nearby weather station. In 2010 , the total rainfall was $710 \mathrm{~mm}$, of which $348 \mathrm{~mm}$ (49\%) fell during the period the roofs were on. Precipitation was less in 2011, with $652 \mathrm{~mm}$ during the whole year, and with $261 \mathrm{~mm}$ (40\%) falling during the period the roofs were on (Weathelab Limited Chelmsford, UK).

The experimental plots, 4 roofed and 4 controls were blocked in the two fields, two replicates in each field, creating a $2 \times 4$ factorial block design. In the investigation, three tree species (Alnus glutinosa [L.] Gaertner, Betula pendula Roth. and Fagus sylvatica L.) were used due to their contrasting shade tolerance, successional chronology and to represent a range of taxonomic, physiological and ecological types. A replacement series design (with inter-tree spacing constant between treatments) was selected because of the experiments objective of being realistic in reflecting the practical realities of how forests comprising monocultures or mixtures of potential canopy tree species could be established (Jolliffe 2000). The site was planted with $60 \mathrm{~cm}$ saplings of each species with inter-tree spacing of $0.8 \mathrm{~m}$, giving a density of 18,042 trees $\mathrm{ha}^{-1}$. A systematic hexagonal planting design (Aguiar et al. 2001) was used to maximise the mixing effect so that, in the threespecies polyculture sub-plots, each tree was surrounded by nearest neighbours of two-conspecific individuals and one and three individuals of the other two species respectively, resulting in each tree having six equidistant neighbours. Each plot was divided into seven planting compartments, and planted in a pattern creating areas of one, two and three species mixtures (Smith et al. 2013). The present study makes use of observations originating from three single species sub-plots containing nine trees of B. pendula, A. glutinosa and F. sylvatica, and a fourth sub-plot which contained a species balanced polyculture of all three species. In the single species plots, the 9 core trees of each subplot were used, in the mixed subplot, 12 additional trees were included for above ground biomass to obtain 7 replicates of each tree species (Fig. 1). The planting pattern of each pair of control and roof plots was rotated by $90^{\circ}$ to avoid potential artefacts introduced by microclimate, soil and uneven growth rates of the different species.

Transparent plastic roofs were mounted between the tree rows on a wooden frame in the 4 plots (Fig. 1). It was constructed such that the soil around the nine core trees was covered, and surrounded by $33 \mathrm{~m}^{2}$ of roofed area in a $2.4 \mathrm{~m}$ buffer zone around the subplot. The roof was 0.4 $0.7 \mathrm{~m}$ above the soil surface with the highest part along a ridge. The ridge ensured that water drained into gutters along two sides. The gutters drained into buckets connected to piped outfalls, leading the water at least $10 \mathrm{~m}$ from the roof. The roofs covered approximately $70 \%$ of the area leaving open strips along the tree rows. The roofs were on for approximately 5 months from 10th June to the first week of November 2010, and 14th April to 13th September 2011. The unroofed plots acted as controls.

\section{Monitoring}

After the roofs were mounted, soil moisture and temperature probes were buried at $5 \mathrm{~cm}$ depth in the middle 
Fig. 1 Schematic diagram of the sub-canopy roofs. A = Alnus glutinosa, B = Fagus sylvatica, $\mathrm{Bi}=$ Betula pendula . The trees marked are the central trees sampled within the species or mixture subplots. The areas between the subplots are two species mixtures. The complete planting pattern is shown in Smith et al. (2013). The position of the soil moisture and temperature sensor is marked as TDR. Light shaded areas show the position of the roof plates. Dark shade areas show the collection gutters, and arrows the outfall collection pipes

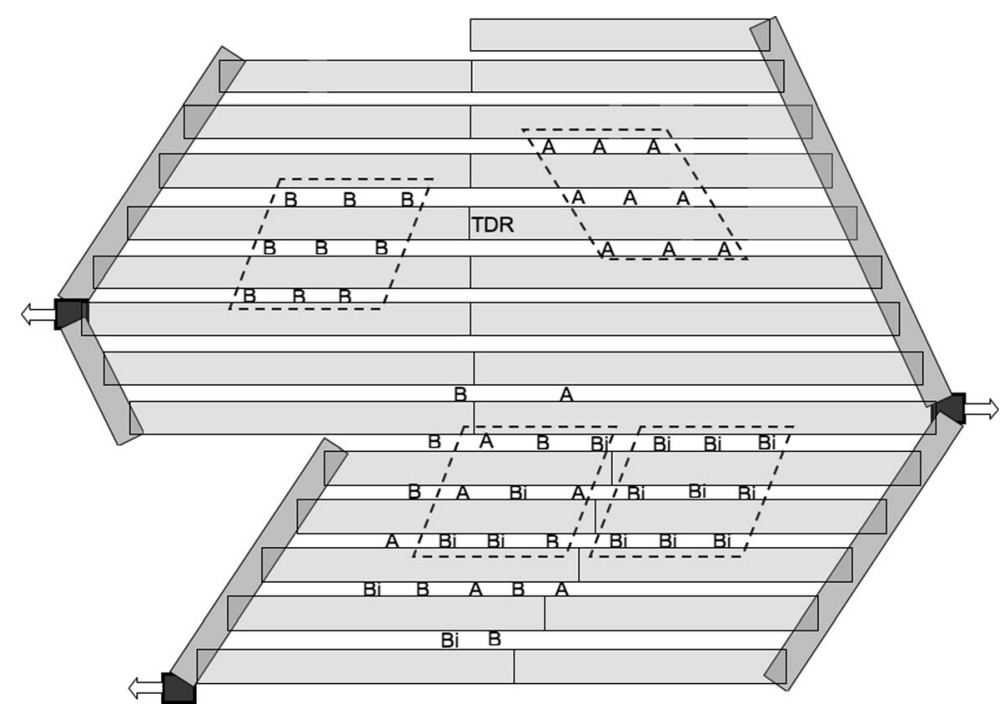

of each plot (in total 4 under roof and 4 in the controls) (in the Fagus sylvatica-Alnus glutinosa mixture, marked "TDR" in Fig. 1), and data logged every 15 min during the experiment (5TM temperature and water content, Decagon Devices, Washington).

The below canopy precipitation was estimated using collectors with a surface area of $0.14 \mathrm{~m}^{2}$ which were placed under Alnus glutinosa, Betula pendula, Fagus sylvatica and the mixed stand in the two former control plots of the FACE-experiment situated in the center of each site (Smith et al. 2013). The above canopy precipitation was estimated using similar collectors in an open field next to the plots. The 10 collectors were emptied after rain events from May to December 2011.

\section{Biomass estimation}

Tree basal area was measured at $1.3 \mathrm{~m}$ height (DBH) in March and at the beginning of November 2010 and April, September and the beginning of December 2011. The measurements of diameter were converted to biomass using algometric equations based on trees of the same age at the same site (Ahmed 2011). At the beginning of the experiment, the total aboveground biomass of the mixed plots used for the drought treatment was $18 \%$ smaller than in the plots used as the controls, although not statistically significant (Fig. 3). It has been shown that there is a positive correlation between the biomass of individual trees and their growth rate as young trees (Quicke et al. 1994). This positive correlation suggests that, even if no treatment were applied, trees in the drought plots would have grown slower than those in the control plots. To compensate for the expected difference in growth rates due to the lower initial biomass of the trees in the drought treatment plots, we calculated the expected growth of the drought treated stand based on the same initial biomass as in the control plots. To do this we first calculated the relationship between growth and standing initial biomass for the individual tree species in the mixed drought treated stand. We then applied the relationship between growth and standing initial biomass of the drought treated trees to the standing initial biomass of the trees in the control plot. To treat the control in the same way, we calculated the relationship between growth and standing initial biomass in the control plots. This relationship was then applied to the initial biomass of the trees in the control stands. Regression parameters for the individual species in the mixed stands of both drought and control stands are presented in table S1.

To measure root biomass soil cores $(\varnothing=8 \mathrm{~cm})$ were taken to $30 \mathrm{~cm}$, and divided into at 0-10, 10-20 and 20$30 \mathrm{~cm}$ soil depths, in March, August and October in 2010, and July and end November in 2011. The samples were taken within the square of trees measured. Sampling positions were distributed over the three quarters around the central tree avoiding the quarter where soil respiration was measured. Soil samples were analyzed for the dry weight of fine roots $<2 \mathrm{~mm}$, as well as percentage soil moisture. Root production was measured by inserting nylon root nets (Normesh, Lancashire) (Lukac and Godbold 2010). The $1 \mathrm{~mm}$ mesh nets 
were $10 \mathrm{~cm}$ wide, and were inserted to a depth of more than $10 \mathrm{~cm}$ under the roofs and in the controls. In each subplot, five root nets were inserted on the 2 nd March 2011. They were harvested by cutting out a soil block around the net on the 16th May, 25th June, 7th August, 13th September and 26th October 2011. The soil was gently removed and the roots were cut to $1 \mathrm{~cm}$ on each side of the mesh (Lukac and Godbold 2010). Roots from the nets were washed, dried at $70{ }^{\circ} \mathrm{C}$ and weighed.

\section{Soil respiration}

From 8th July 2010 until 22nd November 2011, soil respiration was measured in each subplot of Alnus glutinosa, Betula pendula, Fagus sylvatica and mixed stands, in the controls and under the roof. From midApril 2011, soil respiration was also measured in the gap in between the roofs. The respiration was measured every time at the same point which was equidistant from the three surrounding trees. Measurements were made every second week except during the 9th December 2010 to 2nd February 2011, when soil temperature was mostly under $4{ }^{\circ} \mathrm{C}$, and partly covered with snow. Soil respiration was measured for $2 \mathrm{~min}$, with a closed chamber system, using a black chamber with the diameter of $31 \mathrm{~cm}$ and a volume of $8 \mathrm{dm}^{3}$ connected to an IRGAR analyser EMG (pp-systems, Amesbury, USA) (Pumpanena et al. 2004). After the first year of simulated summer drought, soil samples were taken for measurements of heterotrophic soil respiration. In March, before bud break, four samples to $5 \mathrm{~cm}$ soil depth were merged to one composite sample for each stand. The soil was sieved through a $2 \mathrm{~mm}$ sieve and $2 \mathrm{~g}$ was placed in a $10 \mathrm{ml}$ vial. The capsules were incubated for $1.5 \mathrm{~h}$ and $\mathrm{CO}_{2}$ concentration in the head space was then analyzed on a Gas Chromatograph (Varian-450 GC, Agilent, Santa Clara).

\section{Calculations and statistics}

Differences in soil temperature and moisture was tested using independent t-tests and one-way ANOVA. Differences between stands before the experiment was tested with a two-way ANOVA blocked for the two fields. Differences between treatments in growth was tested for each species/mixture using t-tests. Species effect was tested with paired t-test. Effects of treatments on root biomass was tested using a three way ANOVA with soil depth, treatment and species as factors. Turnover of roots was tested with the Mann-Whitney test. Differences between measured and estimates growth for the mixed stands, between years and soil respiration between stands was tested using a paired t-test.

\section{Results}

Soil moisture and temperature

The precipitation measured using the open field collectors was ca. $116 \%$ of that determined by the weather station for the same period. The percentage of precipitation that was intercepted during the time the roofs were on was for Fagus sylvatica $52 \%$, Alnus glutinosa $46 \%$, Betula pendula $48 \%$ and $55 \%$ in the mixture. With the roof construction allowing air circulation under the roof, the soil temperature was the same in both the roof and control soil. Soil moisture, on the other hand, was lower in the drought treatment during the time the roofs were on $(P<0.001)$ (Fig. 2). The soil moisture under the different species and the mixture, as measured three times a year did not differ except for in August in the second year, when Fagus sylvatica under the roof was drier than Alnus glutinosa under the roof $(P=0.046)$.

Above ground biomass and production

At the beginning of the experiment, per $\mathrm{m}^{-2}$, Alnus glutinosa had the largest above ground biomass and Fagus sylvatica the smallest biomass, both in the single

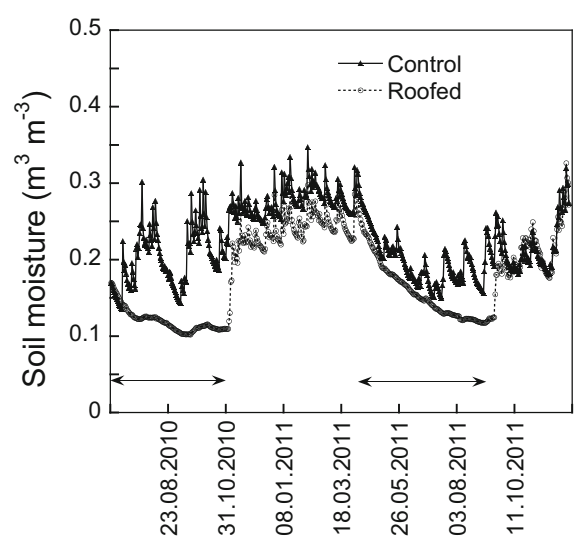

Fig. 2 Volumetric soil water content of control and roofed plots at $5 \mathrm{~cm}$ soil depth. The sensors were situated in the Alnus glutinosaFagus sylvatica mixture between the Alnus glutinosa and the Fagus sylvatica plots, and marked as "TDR" in Fig. 1. Arrows denote the period when the roof was in place 
and mixed stands $(P<0.001)$ (Fig. 3). The biomass in the mixed stands at the beginning of the experiment was higher than predicted from the biomass in the monocultures $(P=0.050)$ (Fig. 3), showing an overyielding of $45 \%$. Alnus glutinosa had the highest biomass in the mixed stand (61\%) followed by Betula pendula $(36 \%)$ and Fagus sylvatica (3\%). The biomass of Alnus glutinosa was larger in the mixed stand than in the monoculture. For Fagus sylvatica it was the opposite, with a higher biomass $\mathrm{m}^{-2}$ in the monoculture than in the mixture $(P=0.001)$, whereas Betula pendula showed no difference in biomass between the monoculture or mixture (data not shown).

After compensating for the initial lower biomass in the drought plots than the control plots at the beginning of the experiment (see methods), there was still significantly lower growth in the drought treatment, as compared to the control in the mixed stand in both 2010 and 2011 (Fig. 4a and b). After two summers with the roofs on, the mixed stand and the Alnus glutinosa stand had grown less than the controls (Fig. 4c). For Betula pendula and Fagus sylvatica there were no significant effects of the roof on growth (Fig. 4 a-c). The overyielding during the experiment in the mixed stands was, after adjustment for the differences in standing biomass, about $30 \%$ in both the control and drought plots (Table 1). In the mixed control, the overyielding was due to Betula pendula growing better in the mixture

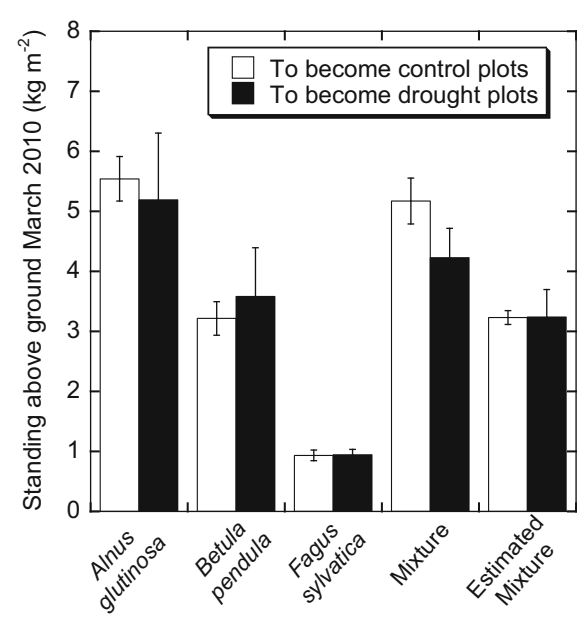

Fig. 3 Standing above ground biomass at the start of the experiment of designated drought and control plots of monocultures of Alnus glutinosa, Betula pendula, Fagus sylvatica and the mixtures. Also shown is the estimated biomass in the mixed stands assuming the individual tree species in the mixtures would have grown at the same rate as in the monocultures. $n=4$. Error bars $=$ Standard error

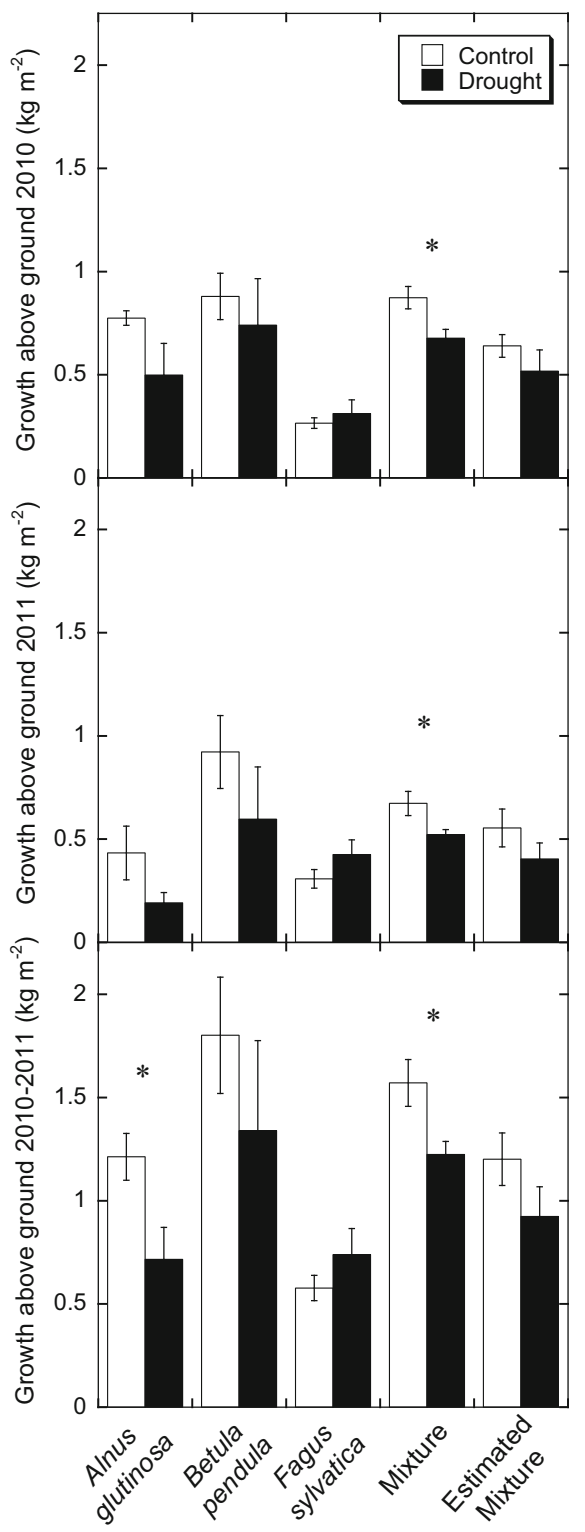

Fig. 4 The increase in above ground biomass in 2010 (a), 2011 (b) and 2010-2011 (c) for monocultures of Alnus glutinosa, Betula pendula, Fagus sylvatica and the mixture of the three as well as the estimated biomass of the mixture based on the growth of the trees when growing in monoculture. $n=4$. Error bars $=$ Standard error. $*=p<0.05$

than in the monoculture $(P=0.118)$. Under drought however, Betula pendula growth declined in the mixture and Alnus glutinosa became the main contributor to the overyielding in the mixed stand $(P=0.031)$ (Fig. 5).

If the two years are compared, both the Alnus glutinosa and the mixed stands (including both drought and control stands) had a lower growth rate in the second year than in the first year ( $P=0.017$ respectively 0.001$)$ (Fig. 4 a and 
Table 1 Overyielding in above ground growth and fine root biomass $(\varnothing<2 \mathrm{~mm})$ in control and the drought stands at the end of the experiment. Overyielding in mean soil respiration during year 1 and year 2 as well as both years combined. The drought stand is further divided into under the roofs and between the roofs when the gaps were measured. $n=4$. n.a $=$ not available

\begin{tabular}{lllll}
\hline & Control & Drought & Under Roof & In Gap \\
\hline Above ground growth & $31 \%$ & $32 \%$ & n.a & n.a \\
Fine root standing biomass $^{\mathrm{a}}$ & $22 \%$ & $28 \%$ & $16 \%$ & $41 \%$ \\
Soil respiration year 1 $^{\mathrm{b}}$ & $0.7 \%$ & n.a & $-0.9 \%$ & n.a \\
Soil respiration year 2 $^{\mathrm{c}}$ & $7.4 \%$ & $4.1 \%$ & $0 \%$ & $12 \%$ \\
Soil respiration whole experiment & $3.4 \%$ & n.a & $-0.6 \%$ & n.a \\
\hline
\end{tabular}

${ }^{a}$ The over yielding in standing root biomass before the experiment started was $18 \%$

b (8/7 2010-6/4-2011)

c (19/4 2011-22/11 2011)

b). In contrast, Betula pendula showed no differences between the years. The growth of the Fagus sylvatica stand tended to be higher in the second year compared to the first year $(27 \%, p=0.061)$. The overyielding of the mixed stand was similar in both years in both the control and drought treatments (Fig. $4 \mathrm{a}$ and b).

\section{Root production and biomass}

The production of fine roots determined with ingrowth nets in 2011 is shown in Fig. 6. In the control, fine root production began between end of June and the beginning of August in the Fagus sylvatica monoculture and the mixed stand. Fine root production in Alnus glutinosa and Betula pendula was highest in the period 7th August to 13 th September. In the drought treatment, almost no

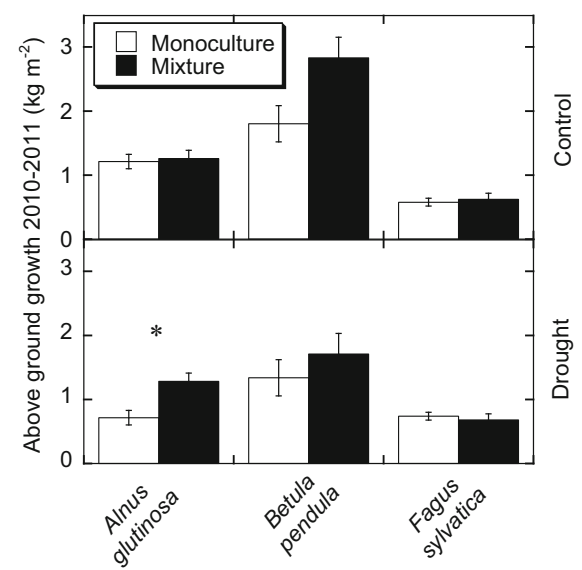

Fig. 5 The increase in above ground biomass during 2010-2011 of Alnus glutinosa, Betula pendula and Fagus sylvatica grown in monoculture and mixture in control plots (upper panel) and drought plots (lower panel). $n=4$. Error bars $=$ Standard error. $*=p<0.05$ fine root production occurred throughout the period that the roof was on. Six weeks after the roofs were removed, on the 26th October, fine root production was detected in the drought plots of Fagus sylvatica and the mixed stand, but only very little in the monocultures of Alnus glutinosa and Betula pendula.

After the first year of drought in 2010, only in Betula pendula was the fine root standing biomass lower in the drought plots compared to the controls (Fig. 7 and Table S2). In the Fagus sylvatica monocultures, fine root biomass was significantly greater under the roofs in August 2010, especially in the upper soil layer (Table. S2). In the second year 2011, fine root biomass was significantly lower under the roofs than in the control for

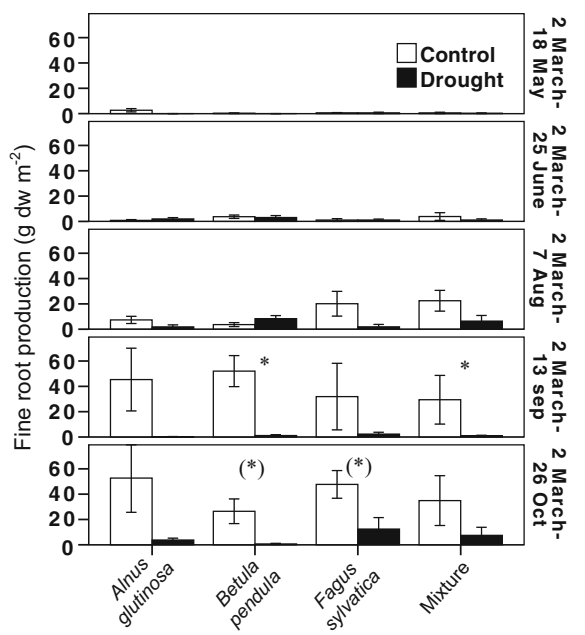

Fig. 6 Root production in control and drought plots of Alnus glutinosa, Betula pendula, Fagus sylvatica and mixed stands of the three tree species in the growing season 2011. Per plot five root nets of $10 \mathrm{~cm}$ width were buried to $10 \mathrm{~cm}$ soil depth in March and one net harvested at five occasions until end of October. $n=4$. Error bars $=$ Standard error. $*=p<0.05,(*)=p<0.1$ 
Fig. 7 Fine root biomass ( $<2 \mathrm{~mm}$ ) to $30 \mathrm{~cm}$ soil depth in Alnus glutinosa, Betula pendula, Fagus sylvatica and mixed stands of the three tree species at 5 time points from March 2010 till November 2011, under the roofs, in the gaps between the roofs (last two points only) and in the controls. The estimated fine root biomass in the mixed stands assumes the individual tree species in the mixtures would have the same root biomass as in the monocultures. $n=4$. Error bars $=$ Standard error. For data on root biomass at 0-10, 10-20 and 20-30 cm, see table $\mathrm{S} 2$.

$*=p<0.05$

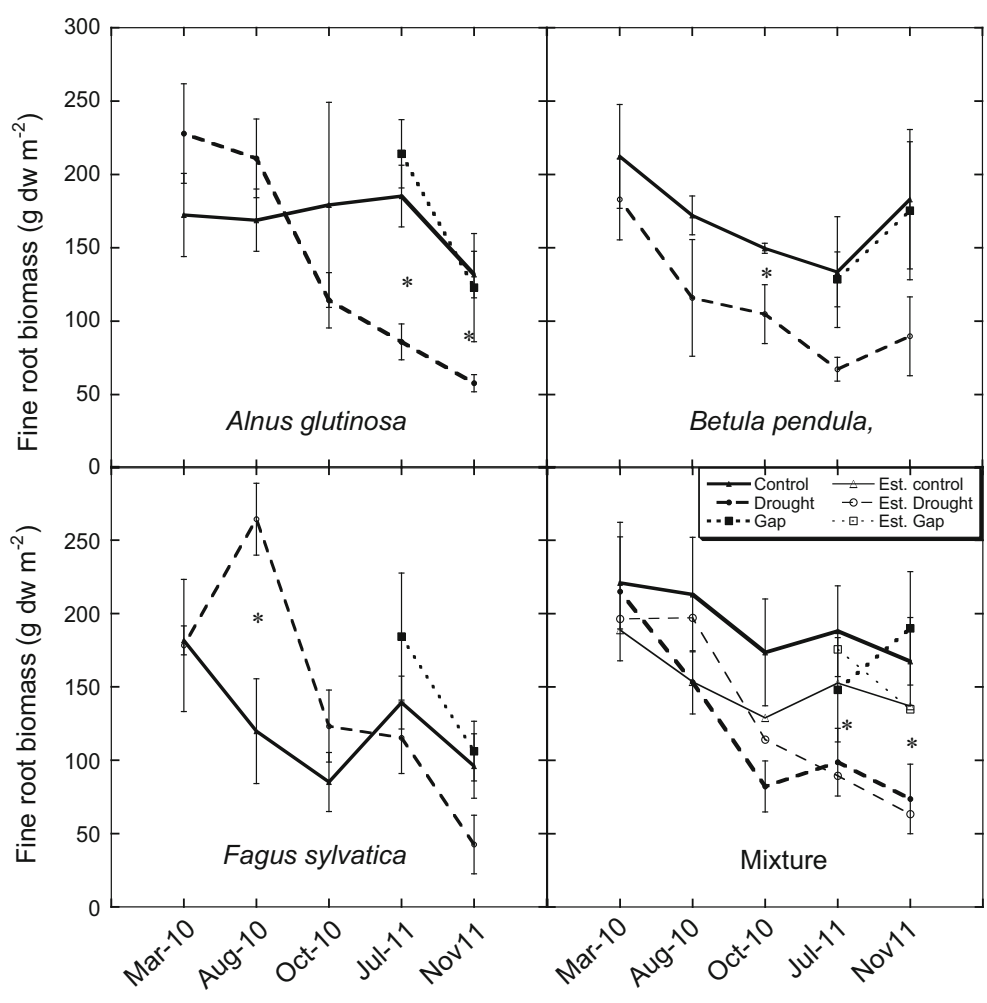

both the Alnus glutinosa monoculture and the mixed stand. In the Fagus sylvatica and Betula pendula monocultures, no significant effect of drought was shown, although the fine root biomass of Betula pendula was in on average $51 \%$ lower under drought. In 2011, the root biomass under the gaps in the drought plots was similar to the root biomass in the control. Before the experiment, the overyielding belowground was $18 \%$. At the end of the second year, the overyielding of fine root biomass was over $22 \%$ in the control and $28 \%$ in the drought treatment taking the gaps into account, but

Table 2 Turnover of fine roots in stands of Alnus glutinosa, Betula pendula, Fagus sylvatica and mixed stands of the three species, calculated as the root growth from 2nd March to 13th September not statistically significantly different (Table 1, Fig. 7). Under the roofs there was $16 \%$ overyielding, whereas in the gaps between the roof segments it was almost twice as high as in the control (41\%) (Table 1).

Based on the root growth and the standing biomass (mean of July and November), the fine root turnover was calculated. When the roofs were taken off in midSeptember, fine root turnover was in the top $10 \mathrm{~cm}$ general lower in drought plots than in the control $(P=0.001)$, but was not significant different between species. (Table 2). At the end of October, fine root

2011 divided by the mean of the standing biomass measured in July and November 2011, and root growth from 2nd March to the 26th October 2011 divided by the same biomass. $n=4$

\begin{tabular}{|c|c|c|c|c|}
\hline & \multicolumn{4}{|c|}{ Turnover rate $\left(\mathrm{a}^{-1}\right)$} \\
\hline & \multicolumn{2}{|l|}{ 13th September } & \multicolumn{2}{|l|}{ 26th October } \\
\hline & Control & Drought & Control & Drought \\
\hline Alnus glutinosa & $0.478 \pm 0.240$ & $0.004 \pm 0.004$ & $0.662 \pm 0.357$ & $0.088 \pm 0.035$ \\
\hline Betula pendula & $0.795 \pm 0.250$ & $0.032 \pm 0.020$ & $0.411 \pm 0.182$ & $0.013 \pm 0.009$ \\
\hline Fagus sylvatica & $0.600 \pm 0.539$ & $0.091 \pm 0.054$ & $0.656 \pm 0.073$ & $0.397 \pm 0.315$ \\
\hline Mixture & $0.253 \pm 0.148$ & $0.017 \pm 0.014$ & $0.350 \pm 0.163$ & $0.187 \pm 0.141$ \\
\hline
\end{tabular}


turnover was still lower in the drought plots than in the control $(P=0.003)$, but the difference had decreased in Betula pendula and the mixed stand (Table 2). The rootshoot ratio (fine roots $<2 \mathrm{~mm}$ and above ground biomass) did not differ between the treatments.

\section{Respiration}

Alnus glutinosa had the highest respiration followed by Betula pendula and Fagus sylvatica in both in the controls and the drought plots $(P<0.05)$. During both growing seasons when the roofs were on, the mean soil respiration for all stands was significantly lower under the roof than in the control $(P<0.001)$ (Fig. 8.) The decrease due to drought was largest in Alnus glutinosa $(-24 \%)$ and smaller in Fagus sylvatica and Betula pendula (both - $18 \%$ ). The mixed stand had an intermediate value of $22 \%$. Respiration in the gaps between the roof segments was similar to the control plots. When the roofs were on, soil respiration in the mixed stands (control and drought) was not different during the first summer from that estimated for the monocultures. In the second year, the control mixed stands had a higher mean soil respiration than would have been estimated from the monocultures $(8.5 \%, P=0.005)$, and continued to be higher after the roofs had been removed (4.26\%, $P=0.015$ ) (Table 1). This was also the case for the gaps between the roofs, when the roofs were still on $(10.4 \%$, $P=0.005)$ and after $(16 \%, P=0.089)$ (Table 1$)$. In the second year, under the roofs, respiration in the mixed stand was not higher than estimated from the monocultures $(P=0.49)$ (Fig. 8) (Table 1). For the whole duration of the experiment, soil respiration was $3.4 \%$ higher in the mixed stand controls, than that estimated from the monocultures $(P=0.029)$, whereas in the drought plots there was no difference $(P=0.935)$ (Table 1). Heterotrophic soil respiration, measured on sieved soil under controlled conditions, showed that there was no significant difference in heterotrophic respiration between the treatments or the different tree species (Fig. S1).

\section{Discussion}

Soil moisture and interception

Frequent, low intensity precipitation events such as those which occur in northern Wales, result in high canopy interception (Johnson 1990). In the work
Fig. 8 Soil respiration measured from July 2010 till November 2011 in Alnus glutinosa, Betula pendula, Fagus sylvatica and the mixture of the three species under the roofs, in the gaps between the roofs (second year only) and in the controls. The arrows indicate the time the roofs were mounted. $n=4$. Error bars $=$ Standard error

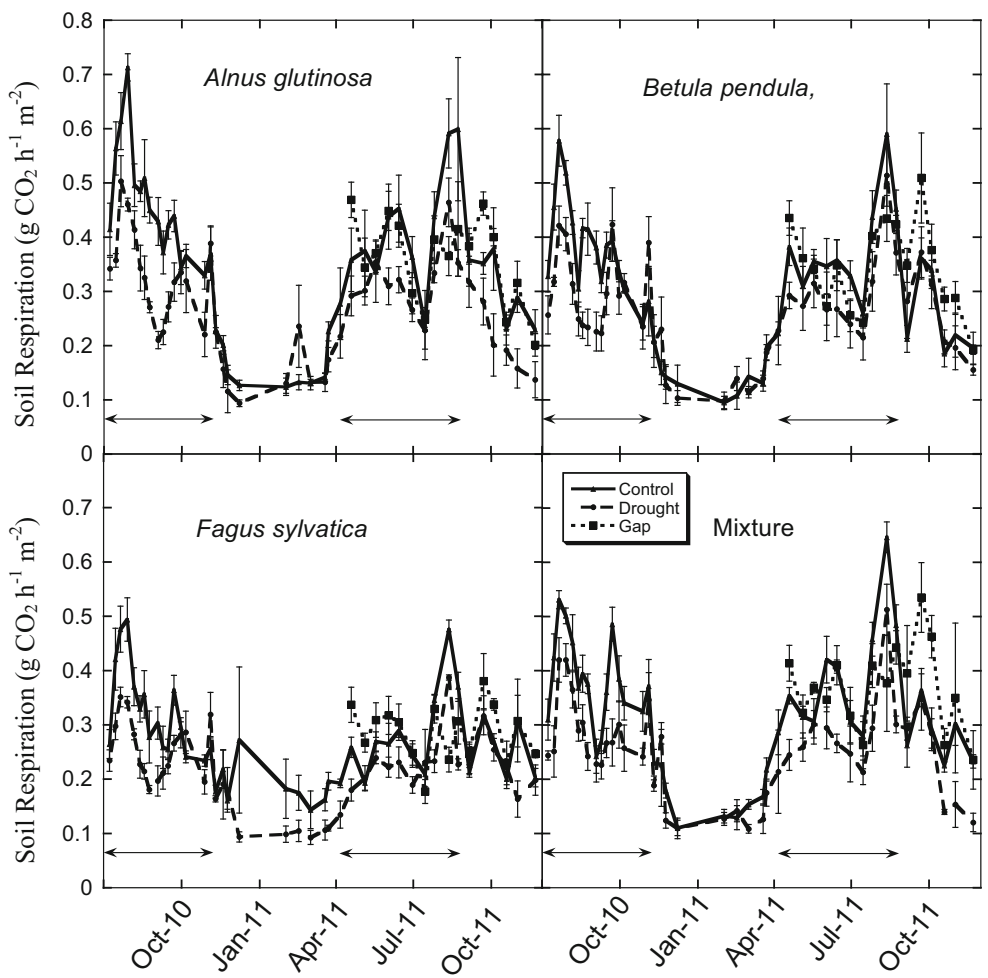


presented here, an average of $50 \%$ canopy interception was determined for the whole stand. Due to the high interception, in 2011 precipitation inputs to the soil due to canopy throughfall were only $130 \mathrm{~mm}$ in the controls. The effects of a reduction of throughfall on the trees could be seen in both above and belowground biomass as well as in soil respiration. Between the years, there were also differences in ambient precipitation. During the time the roofs were on, there was $25 \%$ less precipitation in second year (2011) than in the first year (2010). As between the years the growth of both Alnus glutinosa and the mixed stand was lower in the controls in 2011 than 2010, this suggest that growth in the controls were in 2011 water limited.

Biomass allocation

The response to a decrease in soil moisture content was in the monocultures strongest in Alnus glutinosa for both above and belowground growth. Alnus glutinosa is normally considered as having high soil moisture requirements (Braun 1974), and to be isohydric, thus closing stomata at mild water stress (McDowell et al. 2008). Under sub-optimal soil moisture conditions, Alnus glutinosa showed a greater decrease in Cfixation than other Alnus species (Schrader et al. 2005). Betula pendula followed the same pattern as Alnus glutinosa and has also been considered to be isohydric (Robson et al. 2014). The decrease in root biomass in Alnus glutinosa and Betula pendula due to drought is in accordance with what is commonly observed in broad leaf species (Chiatante et al. 2006; Fort et al. 1998). In contrast, Fagus sylvatica in monoculture showed no tendency towards a decrease in biomass. Fagus sylvatica has a low capacity to maintain leaf water potential during drought compared to other temperate tree species, which defines it as an anisohydric species (Rosner 2012). The less negative effect of water stress on the Fagus sylvatica monoculture in the drought treatment could also be due the relatively large root:shoot ratio of Fagus sylvatica compared to that of Alnus glutinosa and Betula pendula. The pioneer species Betula pendula and Alnus glutinosa had, at the beginning of the experiment 3-4 times larger above ground biomass than Fagus sylvatica. Below ground however, Fagus sylvatica had only about $10 \%$ lower root biomass than Betula pendula and Alnus glutinosa. In records of natural drought events, Fagus sylvatica has high damage and mortality rates during severe drought events (Granier et al. 2007). In a comparison of the species Fagus sylvatica appear to be more tolerant to moderate drought then either Alnus glutinosa and Betula pendula, but appears to have lower resistance to severe drought (Köcher et al. 2009; Wiley and Helliker 2012; Zapater et al. 2013).

The mixed stands had at the start of the experiment a higher biomass than expected based on the monocultures, supporting the idea that mixed stands can better utilize resources than monocultures (Paquette and Messier 2011; Zhang et al. 2012). During the experiment, the mixed plots overyielded by about $30 \%$ in both the control and the drought treatments (Table 1). A similar overyielding of 20-30\% has commonly been found in a broad range of temperate and boreal species when grown in two species mixtures (Pretzsch et al. 2014), and the global mean of overyielding is $24 \%$ in mixed tree stands (Zhang et al. 2012). However in stands of Fagus sylvatica and Picea abies, a decrease in above ground overyielding due to drought was found (Pretzsch et al. 2012), which indicates that site properties affects the overyielding (Forrester 2014).

During the 2-year growth period, in the control only Betula pendula showed higher growth rates in mixture compared to the single species. In the roofed plots, the growth of Betula pendula in mixture was $60 \%$ of that in the control mixture. For Alnus glutinosa in the mixed plots under drought, growth was not effected. Thus whereas in the mixed species plots of the control overyielding was primarily due to Betula pendula, under low soil moisture overyielding was due to both Alnus glutinosa and Betula pendula. A lower sensitivity to drought by Alnus glutinosa when grown in mixture than in monoculture has also been shown by Schrader et al. (2005). This reaction pattern is juxtaposed to that suggested from modelling (Bittner et al. 2010). Bittner et al. (2010) suggested that species that are drought tolerant in monocultures should outcompete drought sensitive species when grown in a mixture, due to more efficient water use. A higher water use efficiency of specific species in mixed stands has been found also in other studies (In Forrester 2015). Similar to (DeClerck et al. 2006), we did not find any evidence that stand resistance to drought was higher in a mixture as compared to monocultures, but that the relative resistance of the individual species changed when grown in mixture as compared to monocultures. 
Fine roots

The response of the trees found in this study may be a result of different rooting strategies used by the different species, which been shown is a key factor for trees to tolerate water stress (Zapater et al. 2013). A clear difference in response of the different tree species to low soil moisture was seen between the years. In the first year, the fine root biomass in Alnus glutinosa and Betula pendula was unaffected or decreased by lower soil moisture, but the fine root biomass of Fagus sylvatica significantly increased. In mature Fagus sylvatica, an increase in fine root biomass primarily in the surface layers was found in response to the natural drought in Europe in 2003 (Mainiero and Kazda 2006). In the second year, the fine root biomass of Alnus glutinosa and the mixture decreased significantly under lower soil moisture content, but there was no statistically significant response in either Fagus sylvatica or Betula pendula. Many studies have shown that fine root biomass of tree seedlings is relatively insensitive to a decrease in soil moisture content (Joslin et al. 2000).

In the work presented here, in the gaps between the roof plates a similar fine root biomass was determined to that in the controls. As the gaps were only $30 \%$ of the total surface area, and no compensatory increase in fine root biomass was determined, for the whole rooting area, fine root biomass decreased for Betula pendula, Alnus glutinosa and the mixture, but was only statistically significantly in Alnus glutinosa and the mixture.

Under the roofed areas, root production in the top $10 \mathrm{~cm}$ of the soil was strongly supressed by decreased soil water content in all species. In the split root experiment of Fort et al. (1998) fine root growth decreased over time in the dry compartment, but not the wet compartment. We were technically unable to measure root production in the gaps as the area is too small for repeated sampling. But, if it is assumed that the root production in the gaps was same as in the controls, then over the entire roof area, fine root production would be less than half in the drought treatment compared to the control.

As a consequence of the low fine root production, but relatively little change in standing fine root biomass (Table S2), fine root turnover in the top $10 \mathrm{~cm}$ was very low in the drought treatment while the roof was on (Fig.8). In a stand of mixed broad leaves (Quercus, Acer and Nyssa), Joslin et al. (2000) also showed lower rates of fine root turnover in at lower soil moisture contents also in a throughfall removal experiment. After the roof was removed, and the soil rewetted, fine root production restarted, and fine root turnover could again be determined. Fine root production was shown in all species, but was highest in Fagus sylvatica. The rates of fine root turnover in the rewetting soil did not reach or exceed those found in the control soils for any species, suggesting that there was no suddenly loss of fine roots or decomposition of fine roots as soil moisture contents increased. This in turn suggests that the fine roots survived the period of low soil moisture.

In the control, there were differences in the timing of root growth. In Fagus sylvatica and mixed stand main root growth period was in July whereas for Alnus glutinosa and Betula pendula it was in August. McCormack et al. (2014) also found a large variation in root phenology in a range of temperate trees species, but could find no clear pattern for the timing of root growth in relation to aboveground growth or leaf phenology. The early root growth of Fagus sylvatica may be related to the species being late successional compared to either Alnus glutinosa or Betula pendula. In the mixed stand, root production was, as in the monocultures, supressed by drought, but as in the Fagus sylvatica stand root production in the drought plots increased after the roofs were removed. It is very possible that the Fagus sylvatica drove this recovery in root production in the mixed stand.

An overyielding of $18 \%$ was shown for fine root biomass in the mixed stand at the beginning of the experiment, which remained relatively unchanged in the control (22\%) after 2 years. (Table 1). However, in the roof plots it slightly increased to $28 \%$. A differences in overyielding between the fine roots sampled under the roof strips (16\%) and in the gaps between the roof strips $(41 \%)$ was clearly seen. We could not distinguish the contribution of fine roots of the different species to the overyielding in the gaps, but this is clearly an indication of preferential foraging of resource rich soil patches. Exploitation of resource rich patch has often be shown in non-woody plants (Hutchings and John 2004), but also for water (Eissenstat and Caldwell 1988) and Mg rich patches (Zhang and George 2009) in woody plants.

\section{Soil respiration}

Total soil respiration is a mixture of heterotrophic and autotrophic respiration, both of which are usually 
negatively affected by drought (Burton et al. 1998; Raich and Schlesinger 1992). In most studies heterotopic respiration has been shown to decline more than the autotrophic respiration under drought (Broken et al. 2006; Wang et al. 2014), but the opposite has also been found (Carbone et al. 2011; Lavigne et al. 2004). In the study presented here, autotrophic and heterotopic respiration were not separated, but as in winter, heterotrophic soil respiration was similar between the stands (Fig. S1), in summer, most of the differences in soil respiration between stands was probably due to differences in autotrophic respiration. The higher soil respiration in the Alnus glutinosa stand than in the Fagus sylvatica and Betula pendula stands is a reflection of the larger biomass and growth of Alnus glutinosa as compared to Fagus sylvatica and Betula pendula (Janssens et al. 2001; Raich and Tufekciogul 2000). The decrease in respiration due to drought was also largest in Alnus glutinosa, which reflects the large negative response on below and above ground biomass by Alnus glutinosa during drought.

Soil respiration in the mixed stands in the first year showed hardly any overyielding. In the second year, there was overyielding of respiration in the control and in the gaps between the roofs, but not under the roofs (Table. 1). Dias et al. (2010) showed for grasslands and Forrester et al. (2006a) for forests that the overyielding in respiration was due to the higher productivity in the mixed stands than in the monoculture. The lack of overyielding in autotrophic respiration under the roofs may be due low root metabolic activity, because of preferential allocation of resources to the fine roots in roof gaps in the mixed stands. This shows that the overyielding in soil respiration follows the development of the fine roots both spatially and temporally.

\section{Conclusion}

No evidence was found that mixed stands have a higher resistance against drought compared to monocultures. Both above and belowground overyielding were unaffected by lower soil moisture, thus higher stress did not lead to larger facilitation in the mixed stand. However, this does not mean that it is possible to predict the response to drought by mixtures based on the response of the tree species grown in monocultures. Alnus glutinosa the species that reduced growth and respiration most in monocultures under drought had a lesser response to drought in mixture. This shows that the response to stress of a species estimated in monoculture may not be applicable when growing in a mixture, which has considerable implications for estimating the response of mixed forest to climate change.

Acknowledgments We thank Llinos Gwar Huges and Mark Wyn Hughes at Henfaes Research Centre for their support. The experimental facility and HG were supported by the INTERREG IVB North-West Europe project 003 A ForeStClim.

Open Access This article is distributed under the terms of the Creative Commons Attribution 4.0 International License (http://creativecommons.org/licenses/by/4.0/), which permits unrestricted use, distribution, and reproduction in any medium, provided you give appropriate credit to the original author(s) and the source, provide a link to the Creative Commons license, and indicate if changes were made.

\section{References}

Aguiar FC, Ferreira MT, Moreira I (2001) Exotic and native vegetation establishment following channelization of a western Iberian river. Regul Rivers Res Manag 17:509-526. doi: 10.1002/rrr.642.abs

Ahmed IU (2011) Ecosystem carbon dynamics - asinfluenced by tree species and mixture in temperate diciduos woodland. $\mathrm{PhD}$. Bangor University

Aspelmeier S, Leuschner C (2006) Genotypic variation in drought response of silver birch (Betula Pendula Roth): leaf and root morphology and carbon partitioning. Trees (Berl) 20:42-52

Bauhus J, Messier C (1999) Soil exploitation strategies of fine roots in different tree species of the southern boreal forest of eastern Canada. Can J For Res 29:260-273

Bittner S, Talkner U, Krämer I, Beese F, Hölscher D, Priesack E (2010) Modeling stand water budgets of mixed temperate broad-leaved forest stands by considering variations in species specific drought response. Agric For Meteorol 150: $1347-1357$

Bolte A, Villanueva I (2006) Interspecific competition impacts on the morphology and distribution of fine roots in European beech (Fagus Sylvatica L.) and Norway spruce (Picea Abies (L.) karst.). Eur J For Res 125:15-26

Braun HJ (1974) Rhytmus und Grösse von Wachstum, Wasserverbrauch und Produktivität des Wasserverbrauches bei Holzpflanzen. Allgemeine Forst- und Jagdzeitung 145: 81-86

Breda N, Huc R, Granier A, Dreyer E (2006) Temperate forest trees and stands under severe drought: a review of ecophysiological responses, adaptation processes and long-term consequences. Ann For Sci 63:625-644

Broken W, Savage K, Davidson EA, Trumbore SE (2006) Effects of experimental drought on soil respiration and radiocarbon 
efflux from a temperate forest soil. Glob Chang Biol 12:177193

Burton AJ, Pregitzer KS, Zogg P, Zak DR (1998) Drought reduces root resperation in suger maple forests. Ecol Appl 8:771-778

Carbone MS, Still CJ, Ambrose AR, Dawson TE, Williams AP, Boot CM, Schaeffer SM, Schimel JP (2011) Seasonal and episodic moisture controls on plant and microbial contributions to soil respiration. Oecologia 167:265-278

Chiatante D, Di lorio A, Sciandra S, GS S, Mazzoleni S (2006) Effect of drought and fire on root development in Quercus Pubescens Willd. And Fraxinus Ornus L. Seedlings. Environ Exp Bot 56:190-197

Ciais P, Reichstein M, Viovy N, Granier A, Ogêe J, Allard V, Aubinet M, Buchmann N, Bernhofer C, Carrara A, Chevallier F, De Noblet N, Friend AD, Friedlingstein P, Grünwald T, Heinesch B, Keronen P, Knohl A, Krinner G, Loustau D, Manca G, Mattecci G, Miglietta F, Ourcival JM, Papale D, Pilegaard K, Rambal S, Seufert G, Soussana JF, Sanz MJ, Schulze ED, Vesala T, Valentini R (2005) Europewide reduction in primary productivity caused by the heat and drought in 2003. Nature (London) 437:529-533

DeClerck AAJ, Barbour MG, Sawyer JO (2006) Species richness and stand stability in conifer forests of sierra Nevada. Ecology (N Y) 87:2789-2799

del Rio M, Schütze G, Pretzsch H (2014) Temporal variation of competition and facilitation in mixed species forests in Central Europe. Plant Biol (N Y) 16:166-176

Dias ATC, Van Ruijven J, Berendse F (2010) Plant species richness regulates soil respiration through changes in productivity. Oecologia 163:805-813

Eissenstat DM, Caldwell MM (1988) Seasonal timing of root growth in favorable microsites. Ecology:870-873

Ellenberg H (1996) Vegetation mitteleuropas mit den Alpen. Ulmer, Sturttgart

Fischer A, Lindner M, Abs C, Lasch P (2002) Vegetation dynamics in central European forest ecosystems (near-natural as well as managed) after storm events. Folia Geobot 37:17-32

Forrester DI (2014) The spatial and temporal dynamics of species interactions in mixed-species forests: from pattern to process. For Ecol Manag 312:282-292

Forrester DI (2015) Transpiration and water-use efficiency in mixed-species forests versus monocultures: effects of tree size, stand density and season. Tree Physiol. doi:10.1093/ treephys/tpv1011

Forrester DI, Bauhus J, Cowie AL (2006a) Carbon allocation in a mixed-species plantation of Eucalyptus Globulus and Acacia Mearnsii. For Ecol Manag 233:275-284

Forrester DI, Bauhus J, Cowie AL, Vanclay JK (2006b) Mixedspecies plantations of eucalyptus with nitrogen-fixing trees: a review. For Ecol Manag 233:211-230

Fort C, Muller F, Label P, Granier A, Dreyer E (1998) Stomatal conductance, growth and root signaling in Betula Pendula seedlings subjected to partial soil drying. Tree Physiol 18: 769-776

Gower ST, Vogt KA, Griee CC (1992) Carbon dynamics of rocky mountains Douglas-fir - influence of water and nutrient availability. Ecol Monogr 62:43-65

Granier A, Reichstein M, Brêda N, Janssens IA, Falge E, Ciais P, Grünwald T, Aubinet M, Berbigier P, Bernhofer C, Buchmann N, Facini O, Grassi G, Heinesch B, Ilvesniemi H, Keronen P, Knohl A, Köstner B, Lagergren F, Lindroth A,
Longdoz B, Loustau D, Mateus J, Montagnani L, Nys C, Moors E, Papale D, Peiffer M, Pilegaard K, Pita G, Pumpanen J, Rambal S, Rebmann C, Rodrigues A, Seufert G, Tenhunen T, Vesala T, Wang Q (2007) Evidence for soil water control on carbon and water dynamics in European forests during the extremely dry year: 2003. Agric For Meteorol 143:123-145

Grossiord C, Granier A, Ratcliffe S, Bouriaud O, Bruelheide H, Chećko E, Forrester DI, Dawud SM, Finér L, Pollastrini M (2014) Tree diversity does not always improve resistance of forest ecosystems to drought. Proc Natl Acad Sci 111:1481214815

Hutchings MJ, John EA (2004) The effects of environmental heterogeneity on root growth and root/shoot partitioning. Ann Bot 94:1-8

IPCC (2014) Climate Change 2014: Impacts, Adaptation, and Vulnerability. Part A: Global and Sectoral Aspects. Contribution of Working Group II to the Fifth Assessment Report of the Intergovernmental Panel on Climate Change. In: CB Field, VR Barros, DJ Dokken, KJ Mach, MD Mastrandrea, TE Bilir, M Chatterjee, KL Ebi, YO Estrada, RC Genova, B Girma, ES Kissel, AN Levy, S MacCracken, PR Mastrandrea, LL White (eds), Cambridge and New York.

Jacob A, Hertel D, Leuschner C (2013) On the significance of belowground overyielding in temperate mixed forests: separating species identity and species diversity effects. Oikos 122:463-473

Janssens I, Lankreijer H, Matteucci G, Kowalski A, Buchmann N, Epron D, Pilegaard K, Kutsch W, Longdoz B, Grünwald T (2001) Productivity overshadows temperature in determining soil and ecosystem respiration across European forests. Glob Chang Biol 7:269-278

Johnson R (1990) The interception, throughfall and stemflow in a forest in highland Scotland and the comparison with other upland forests in the UK. J Hydrol 118:281-287

Jolliffe PA (2000) The replacement series. J Ecol 88:371-385. doi: 10.1046/j.1365-2745.2000.00470.x

Joslin JD, Wolfe MH, Hanson PJ (2000) Effects of altered water regimes on forest root systems. New Phytol 147:117-129

Kelty MJ (2006) The role of species mixtures in plantation forestry. For Ecol Manag 233:195-204

Köcher P, Gebauer T, Horna V, Leuschner C (2009) Leaf water status and stem xylem flux in relation to soil drought in five temperate broad-leaved tree species with contrasting water use strategies. Ann For Sci 66. doi:10.1051/forest/2008076

Lavigne M, Foster R, Goodine G (2004) Seasonal and annual changes in soil respiration in relation to soil temperature, water potential and trenching. Tree Physiol 24:415-424

Lebourgeois F, Gomez N, Pinto P, Mérian P (2013) Mixed stands reduce Abies Alba tree-ring sensitivity to summer drought in the Vosges mountains, western Europe. For Ecol Manag 303: 61-71

Loreau M, Naeem S, Inchausti P, Bengtsson J, Grime JP, Hector A, Hooper DU, Huston MA, Raffaelli D, Schmid V, Tilman D, Wardle DA (2001) Biodiversity and ecosystem functioning: current knowledge and future challenges. Science (Wash D C) 294:804-808

Lukac M, Godbold DL (2010) Fine root biomass and turnover in southern taiga estimated by root inculusion nets. Plant Soil 333:505-513 
Mainiero R, Kazda M (2006) Depth-related fine root dynamics of Fagus Sylvatica during exceptional drought. For Ecol Manag 237:135-142

Mattson WJ, Haack RA (1987) The role of drought in outbreaks of plant-eating insects. Bioscience:110-118

McCormack ML, Adams TS, Smithwick EA, Eissenstat DM (2014) Variability in root production, phenology, and turnover rate among 12 temperate tree species. Ecology 95:22242235

McDowell NG (2011) Mechanisms linking drought, hydraulics, carbon metabolism, and vegetation mortality. Plant Physiol (Rockv) 155:1051-1059

McDowell N, Pockman WT, Allen CD, Breshears DD, Cobb N, Kolb T, Plaut J, Sperry J, West A, Willams DG, Yepez EA (2008) Mechanisms of plant survival and mortality during drought: why do some plants survive while others succumb to drought? New Phytol 178:719-739

Meier IC, Leuschner C (2008) Belowground drought response of European beech: fine root biomass and carbon partitioning in 14 mature stands across a precipitation gradient. Glob Chang Biol 14:2081-2095

Neumann RB, Cardon ZG (2012) The magnitude of hydraulic redistribution by plant roots: a review and synthesis of empirical and modeling studies. New Phytol 194:337-352

Osunubi O, Davies WJ (1981) Root growth and water relations of oak and birch seedlings. Oecologia (Berl) 51:343-350

Paquette A, Messier C (2011) The effect of biodiversity on tree productivity: from temperate to boreal forests. Glob Ecol Biogeogr 20:170-180

Parker MM, Van Lear DH (1996) Soil heterogeneity and root distribution of mature loblolly pine stands in piedmont soils. Soil Sci Soc Am J 60:1920-1925

Peuke AD, Schraml C, Hartung W, Rennenberg H (2002) Identification of drought-sensitive beech ecotypes by physiological parameters. New Phytol 154:373-387

Pretzsch H, Dieler J, Seifert T, Rötzer T (2012) Climate effects on productivity and resource-use efficiency of Norway spruce (Picea Abies [L.] karst.) and European beech (Fagus Sylvatica [L.]) in stands with different spatial mixing patterns. Trees (Berl) 26:1343-1360

Pretzsch H, Rötzer T, Matyssek R, Grams TEE, Gäberle K-H, Pritsch K, Kerner R, Munch JC (2014) Mixed Norway spruce (Picea abies [L.] Karst) and European beech (Fagus sylvatica [L.]) stands under drought: from reaction pattern to mechanism. Trees (Berl): doi:10.1007/s00468-00014-0103500469.

Pronk AA, De Willingen P, Heuvelink E, Challa H (2002) Development of fine and coarse roots of Thuja Occidentalis 'Brabant' in non-irrigated and drip irrigated field plots. Plant Soil 243:161-171

Pumpanena J, Kolari P, Ilvesniemi H, Minkkinen K, Vesala T, Niinistö S, Lohila A, L T, Morero M, Pihlatie M, Janssens I, Curiel Yuste J, JM G, Reth S, J-A S, Savage K, Kutsch W, Østreng G, Zieglerm W, Anthonim P, Lindroth A, Hari P (2004) Comparison of different chamber techniques for measuring soil $\mathrm{CO}_{2}$ efflux. Agric For Meteorol 123:159-176
Quicke HE, Meldahl RS, Kush JS (1994) Basal area growth of individual trees: a model derived from a regional longleaf pine growth study. For Sci 40:528-542

Raich J, Schlesinger WH (1992) The global carbon dioxide flux in soil respiration and its relationship to vegetation and climate. Tellus B 44:81-99

Raich JW, Tufekciogul A (2000) Vegetation and soil respiration: correlations and controls. Biogeochemistry 48:71-90

Ranney TG, Bir RE, Skroch WA (1991) Comparative drought resistance among six species of birch (Betula): influence of mild water stress on water relations and leaf gas exchange. Tree Physiol 8:351-360

Robson tM, Hartikainen SM, Aphalo PJ (2014) How does solar ultraviolet-B radiation improve drought tolerance of silver birch (Betula pendula Roth.) seedlings? Plant, Cell and Environment doi:10.1111/pce.12405.

Rosner S (2012) Acoustic emission related to stomatal closure of four deciduous broad-leaved woody species. 30th European Conference on Acoustic Emission Testing (EWGAE). EWGAE, Granada.

Schrader JA, Gardner SJ, Graves WR (2005) Resistance to water stress of Alnus Maritima: intraspecific variation and comparisons to other alders. Environ Exp Bot 53:281-298

Smith AR, Lukac M, Hood R, Healey JR, Miglietta F, Godbold DL (2013) Elevated CO2 enrichment induces a differential biomass response in a mixed species temperate forest plantation. New Phytol 198:156-168

Thomas F (2000) Vertical rooting patterns of mature quercus trees growing on diffrent soil types in nothern Germany. Plant Ecol 147:95-103

Tilman D, Downing JA (1994) Biodiversity and stability in grasslands. Nature 367:363-365

van der Molen MK, Dolman AJ, Ciais P, Eglin T, Gobron N, Law BE, Meir P, Peters W, Phillips OL, Reichstein M, Chen T, Dekker SC, Doubkova M, Friedl MA, Jung M, van der Hurk BJJM, de Jeu RAM, Kruijt B, Ohta T, K. T R, P S, SI S, Sitch S, AJ T, van der Werf GR, Wang G (2011) Drought and ecosystem carbon cycling. Agric For Meteorol 151:765-773

Vandermeer J (1989) The ecology of intercropping. Cambridge University press, Cambridge

Wang Y, Hao Y, Cui XY, Zhao H, Xu C, Zhou X, Xu Z (2014) Responses of soil respiration and its components to drought stress. J Soils Sediments 14:99-109

Wiley E, Helliker B (2012) A re-evaluation of carbon storage in trees lends greater support for carbon limitation to growth. New Phytol 195:285-289

Zapater M, Bréda N, Bonal D, Pardonnet S, Granier A (2013) Differential response to soil drought among co-occurring broad-leaved tree species growing in a 15-to 25-year-old mixed stand. Ann For Sci 70:31-39

Zhang J, George E (2009) Root proliferation of Norway spruce and scots pine in response to local magnesium supply in soil. Tree Physiol 29:199-206

Zhang Y, Chen HY, Reich PB (2012) Forest productivity increases with evenness, species richness and trait variation: a global meta-analysis. J Ecol 100:742-749 